\title{
Antioxidant Properties of Paddy Straw Mushroom [Volvariella volvacea (Bull. ex Fr.)] Sing
}

\author{
A. Sudha ${ }^{*}$, P. Geetha ${ }^{2}$ and M. Rajesh ${ }^{3}$ \\ ${ }^{1}$ Department of Plant Pathology, ${ }^{2}$ Department of Post Harvest Technology Centre, ${ }^{3}$ Centre of \\ Excellence for Millets, Athiyandal, Tamil Nadu Agricultural University, Coimbatore-3, India
}

*Corresponding author

\section{A B S T R A C T}

\section{Keywords}

Volvariella

volvacea,

Antioxidant

properties,

Additives

Article Info

Accepted:

20 January 2019

Available Online:

10 February 2019

\section{Introduction}

The genus Volvariella (paddy straw mushroom) comprised a group of several species, which can be found growing on a variety of substrates in tropical and subtropical regions. $V$. volvacea (Bull. ex Fr.) Sing., is probably the best known species, as it has been traditionally cultivated in Southeast Asia since the $18^{\text {th }}$ century (Chang, 1977). At present time, $V$. volvacea is the third most important cultivated mushroom reaching total world production of 287 metric tones (Chang and Miles, 1993). In India, Su and Seth (1940) have first cultivated straw mushroom but the scientific cultivation using spawn was successfully demonstrated by Thomas et al., (1943). It is commonly known as Chinese mushroom, the most favourite mushroom in South Asian countries because of its excellent delicacy, high protein, aminoacid, vitamins and mineral contents (Thakur and Yadav, 2006). The climatic conditions prevailing in the Indian plains seem to be quite suitable for large scale production of paddy straw mushroom. In recent years, the use of some synthetic antioxidants has been restricted because of 
their possible toxic and carcinogenic effects (Gazzani et al., 1998 and Frankel et al., 1985). This concern has resulted in an increased interest in the investigation of the effectiveness of naturally occurring compounds with antioxidant properties (Duh et al., 1992) foods rich in antioxidants have been shown to play an essential role in the prevention of cardiovascular diseases (Dragsted et al., 1993), neurodegenerative diseases, Parkinson's and Ahlzeimer's diseases (Clarke, 1999 and Joseph et al., 1999) inflammation and problems caused by cell and cutaneous aging (Ames et al., 1993; Gaulejac et al., 1999 Prior and Coa, 2000). Thus the natural antioxidants present in foods and other biological materials have attracted considerable interest because of their presumed safety and potential nutritional and therapeutic effects (Ames et al., 1993).in view of this fact, the present study has been programmed to estimate the non-enzymatic antioxidative substances due to additives in V.volvacea.

\section{Materials and Methods}

\section{Preparation of mushroom bed}

Paddy straw was soaked overnight in cleaned water and stream sterilized at $15 \mathrm{lbs}$ pressure for $30 \mathrm{~min}$. Excess water was drained after steam sterilization and shade dried to have 65 75 per cent moisture content. The substrates was made into small twists of $2.5 \mathrm{~m}$ long and $5-8 \mathrm{~cm}$ dia. weighing about $1.25 \mathrm{~kg}$ (dry weight). Totally four twisted bundles were used for the preparation of circular compact beds. Initially, the twists were made clockwise in a circular fashion. The mycelial discs of $8 \mathrm{~mm}$ dia. were taken from the seven day old actively growing culture and inoculated @ three disc per layer. On the surface layer s various organic and inorganic additives as listed earlier were sprinkled (2 per cent). Likewise totally four twisted bundles were used. The completed beds were pressed tightly on the wooden rack in a polyhouse with sufficient temp $\left(30-35^{\circ} \mathrm{C}\right)$ and humidity (80-85) per cent was maintained. The beds were regularly sprayed with water. The harvested mushrooms were used for assay of antioxidative substances. Non amended additive used as control. Straw bed without additive served as control.

\section{Collection and drying of mushrooms}

Harvested mushrooms were sun-dried separately for $24 \mathrm{~h}$ and dried in an oven at $60^{\circ} \mathrm{c}$ for $30 \mathrm{~min}$. Then, the mushrooms were powdered using pulverizer.

\section{Estimation of non enzymatic antioxidative substances}

Mushroom extracts were assayed for nonenzymatic antioxidants such as total glutathione, total phenols, flavanoides, lycopene, total carotenoids, vitamin $\mathrm{A}$, and vitamin C.

\section{Preparation and extraction of samples}

Five gram of samples from each treatment samples was extracted by stirring with $100 \mathrm{ml}$ of methanol and filtered through Whatmann No. 4 filter paper. The residue was reextracted twice. The sample was lyophilized and residual solvent extract was removed under reduced pressure at $4^{0} \mathrm{c}$ using a rotary evaporator. Extracts were produced in triplicates and used for the analysis of antioxidative substances.

\section{Estimation of total reduced glutathione (Mori et al., 1989)}

Mushroom extract $0.5 \mathrm{ml}$ was mixed with 0.5 $\mathrm{ml}$ of 5\% TCA. The precipitated protein was centrifuged down at $1000 \mathrm{rpm}$ for 10 minutes. $0.1 \mathrm{ml}$ of the supernatant was made upto 1.0 
$\mathrm{ml}$ with sodium phosphate buffer. $2.0 \mathrm{ml}$ of freshly prepared DTNB were added. The absorbance was read after $10 \mathrm{~min}$ at $412 \mathrm{~nm}$ against a reagent blank. A set of standards were also treated in the above manner. The amount of glutathione was expressed as $\mu \mathrm{g}$ /mg protein.

\section{Estimation of total phenols (Sumathi, 1998)}

Pipetted out $0.1 \mathrm{ml}$ of sample into test tubes and the volume was made to $3.0 \mathrm{ml}$ with distilled water. $0.5 \mathrm{ml}$ of Folin-Ciocalteau reagent was added. After 3 minutes, $2.0 \mathrm{ml}$ of $20 \%$ sodium carbonate was added. Mixed thoroughly, and placed in boiling water bath for exactly one minute, cooled and read the absorbance at $650 \mathrm{~nm}$ against a reagent blank. A set of standards were also treated in the above manner. The amount of phenols was expressed as $\mathrm{mg} / \mathrm{mg}$ tissue.

\section{Estimation of flavanoids (Hertog et al., 1992)}

Added $0.5 \mathrm{ml}$ of the sample to a test tube containing $1.25 \mathrm{ml}$ of distilled water. Then added $0.075 \mathrm{ml}$ of $5 \%$ sodium nitrite solution and allowed to stand for $5 \mathrm{~min}$. Added 0.15 $\mathrm{ml}$ of $10 \%$ aluminium chloride, after $6 \mathrm{~min}$ $0.5 \mathrm{ml}$ of $1 \mathrm{M}$ sodium hydroxide was added and the mixture was diluted with another $0.275 \mathrm{ml}$ of distilled water. The absorbance of the mixture at $510 \mathrm{~nm}$ was measured immediately. The flavanoid content was expressed as milligram catechin equivalents /g sample.

\section{Estimation of total lycopene and carotenoids (Gerster, 1997)}

Weighed 5 to $10 \mathrm{~g}$ of the sample. Saponified for about 30 minutes in a shaking water bath at $37^{\circ} \mathrm{c}$ after extracting the alcoholic $\mathrm{KOH}$. Transferred the saponified extract into a separating funnel (packed with glass wool and calcium carbonate) containing 10 to $15 \mathrm{ml}$ of petroleum ether and mixed gently. Taken up the carotenoid pigments into the petroleum ether layer. Transferred the lower aqueous phase to another separating funnel and the petroleum ether extract containing the carotenoid pigments to an amber coloured bottle. Repeated the extraction of the aqueous phase similarly with petroleum ether, until it is colourless. Discarded the aqueous. To the petroleum ether extract added a small quantity of sodium sulphate to remove turbidity. Noted the final volume of the petroleum ether extract and diluted if needed by a known dilution factor. The absorbance at $450 \mathrm{~nm}$ and $503 \mathrm{~nm}$ was noted in a spectrophotometer using petroleum ether as a blank.

\section{Calculation}

Carotenoids $(\mu \mathrm{g})=\frac{\mathrm{Px} 4 \mathrm{xVx} 100}{\mathrm{~W}}$

$\mathrm{P}=$ Optical density of the sample

$\mathrm{V}=$ Volume of the sample

$\mathrm{W}=\mathrm{Weight}$ of the sample

$($ Lycopene $\mathrm{mg} / 100 \mathrm{~g})=$

\subsection{6 x OD sample $\mathrm{x}$ vol made up $\mathrm{x}$ dilution $\mathrm{x} 100$}

$1 \mathrm{x}$ weight of the sample $\mathrm{x} 1000$

\section{Estimation of vitamin A (Nield et al., 1963)}

To $1.0 \mathrm{ml}$ of 10 per cent homogenate $1.0 \mathrm{ml}$ of saponification mixture $(2 \mathrm{~N} / \mathrm{KOH}$ in alcohol) was added and heated under gentle reflux for $20 \mathrm{~min}$ at $60^{\circ} \mathrm{C}$. Twenty five $\mathrm{ml}$ of water was added to the mixture after cooling to room temperature and the solution was transferred to a separating funnel. It was then extracted thrice with using 25,15 and $10 \mathrm{ml}$ of petroleum ether $\left(40-60^{\circ} \mathrm{C}\right)$. The ether extracts were pooled and washed with 50-100 $\mathrm{ml}$ of distilled water repeatedly until the wash water was free of alkali. The petroleum ether 
extract was then dried by adding anhydrous sodium sulphate. The volume of the extract was noted. $3.0 \mathrm{ml}$ of petroleum ether phase was transferred to a cuvette and read at 420 nm against a petroleum ether blank without delay to prevent evaporation of the solvent and destruction of carotenoids by light and marked this reading as $\mathrm{A} 1$. The $\beta$-carotene working standards were measured at $450 \mathrm{~nm}$.

The aliquots were evaporated to dry ness at $60^{\circ} \mathrm{c}$ in a water bath. The residue was taken immediately and $2.0 \mathrm{ml}$ TFA reagent were added to it.

The mixture was rapidly transferred to a cuvette and the absorbance was measured at $620 \mathrm{~nm}$ exactly after the addition of TFA reagent and marked this reading as $\mathrm{A} 2$. The vitamin A working standard was read at 620 nm.

\section{Calculation}

For accurate calculation of the vitamin A content, it was necessary to correct for the absorbance contributed by carotene at 620 nm.

$\mathrm{A}_{3}=\mathrm{A}_{2}-\mathrm{A}_{1}$

$\mathrm{A}_{1}=$ Absorbance of carotene at $450 \mathrm{~nm}$

$\mathrm{A}_{2}=$ Absorbance at $620 \mathrm{~nm}$ due to both carotene and vitamin $\mathrm{A}$.

$\mathrm{A}_{3}=$ Absorbance at $620 \mathrm{~nm}$ of vitamin A.

Sample $=$

$\mathrm{A}_{3} \times \mu \mathrm{g}$ retinol calibarator/cuvette $\mathrm{x} 3 \mathrm{x}$ total volume

$\mathrm{A}_{620}$ retinol calibarator $\mathrm{x} 2 \mathrm{x}$ gram

$3=$ Volume of petroleum ether from $1.0 \mathrm{ml}$ extract

$2=$ Aliquot of the petroleum ether used for the assay

$1=10$ per cent extract taken from initial sample

The results were expressed as $\mu \mathrm{g} / \mathrm{g}$ tissue.

\section{Estimation of vitamin C (Sumathi, 1998)}

One $\mathrm{ml}$ of brominated sample extract was taken and made up the volume to $3.0 \mathrm{ml}$ by adding distilled water. Added $1.0 \mathrm{ml}$ of dinitro phenyl hydrazine reagent followed by 1 to 2 drops of thiourea into each tube. A blank was set as above but with water in place of ascorbic acid solution. Mixed the contents of the tube thoroughly and incubated at $37^{\circ} \mathrm{c}$ for 3 hours. After incubation the tubes were kept in the ice bath. Dissolved the orange red azazone crystals formed by adding $7.0 \mathrm{ml}$ of 80 per cent sulphuric acid drop wise while the tubes were still in the water bath. The tubes in the ice bath were removed and allowed to stand for 30 minutes at room temperature and measured the absorbance at $540 \mathrm{~nm}$. The result is expressed as $\mu \mathrm{g} / \mathrm{g}$ tissue.

\section{Results and Discussion}

The effect of various organic and inorganic additives on the production of non enzymatic antioxidative substances viz., total glutathione, total phenol, flavonoids, lycopene, total carotenoids, vitamin $\mathrm{A}$, and vitamin $\mathrm{C}$ were presented in Table 1.

Among the additives, calcium carbonate amended beds recorded maximum amount of total glutathione $(395.25 \mu \mathrm{g} / \mathrm{g})$, total phenol $(16.72 \mathrm{mg} / \mathrm{g})$, flavonoids $(9.17 \mathrm{mg} / \mathrm{g})$, lycopene $(1.99 \mathrm{mg} / \mathrm{g})$, total carotenoids $(0.35$ $\mu \mathrm{g} / \mathrm{g})$, vitamin A $(6.23 \mu \mathrm{g} / \mathrm{g})$ and vitamin $\mathrm{C}$ $(0.54 \mathrm{mg} / \mathrm{g})$. This was followed by horse gram $(342.50 \mu \mathrm{g} / \mathrm{g} ; 12.05 \mathrm{mg} / \mathrm{g} ; 8.00 \mathrm{mg} / \mathrm{g} ; 1.73$ $\mathrm{mg} / \mathrm{g} ; 0.20 \mu \mathrm{g} / \mathrm{g} ; 4.52 \mu \mathrm{g} / \mathrm{g}$ and $0.43 \mathrm{mg} / \mathrm{g}$ ), gypsum $(210.26 \mu \mathrm{g} / \mathrm{g} ; 13.52 \mathrm{mg} / \mathrm{g} ; 7.40 \mathrm{mg} / \mathrm{g}$; $1.70 \mathrm{mg} / \mathrm{g} ; 0.19 \mu \mathrm{g} / \mathrm{g} ; 4.05 \mu \mathrm{g} / \mathrm{g}$ and 0.42 $\mathrm{mg} / \mathrm{g}$ ) and calcium carbonate + gypsum $(210.0 \mu \mathrm{g} / \mathrm{g} ; 12.68 \mathrm{mg} / \mathrm{g} ; 7.05 \mathrm{mg} / \mathrm{g} ; 1.75$ $\mathrm{mg} / \mathrm{g} ; 0.18 \mu \mathrm{g} / \mathrm{g} ; 3.90 \mu \mathrm{g} / \mathrm{g}$ and $0.41 \mathrm{mg} / \mathrm{g})$. In non-amended medium significantly very less amount of antioxidative substances were recorded. 
Traditionally $V$. volvacea has been grown on rice straw. That tradition earned it the name of paddy straw mushroom (Chang, 1983). The straw mushroom cultivation in tropical/subtropical areas is still less advanced. The climatic condition prevailing in the Indian plains seems to be quit suitable for large scale production. Practically in India a very little improvement in the cultivation technique has been done during the last two decades. Major drawback in the cultivation of Volvariella is the very low biological efficiency (B.E) as compared to other tropical mushrooms. If culture technique improved, it should be cultivated widely and cheaply as other common vegetables which can be consumed regularly by all people. In view of the above facts, the present thesis research was aimed to increase the biological efficiency by utilizing various new cultivation technologies for yield improvement. The results obtained were discussed herein.

\section{Antioxidative substances}

Foods rich in antioxidative substances have been showed to play essential role in the prevention of cardiovascular diseases (Dragsted et al., 1993), cencers (Dragsted et al., 1993), neurogenerative diseases (Joseph et al., 1999), inflammation (Joseph et al., 1999) and cutaneous ageing (Prior and Coa, 2000), The use of synthetic antioxidants has been restricted because of their possible toxic and carcinogenic effects (Gazzani et al., 1998). The present study was therefore aimed to study the natural antioxidative (non-enzymatic) substances viz., total glutothione, total phenol, flavanoides, lycopene, total carotenoids, vitamin $\mathrm{A}$ and vitamini C. Among the additives, calcium carbonate recorded maximum amount of glutothione

(395.25 $\mu \mathrm{g} / \mathrm{g}$, total phenol (16.27 $\mathrm{mg} / \mathrm{g})$, flavanoides $(9.17 \mathrm{mg} / \mathrm{g})$, lycopene $(1.99 \mathrm{mg} / \mathrm{g})$ total carotenoide $(0.35 \mu \mathrm{g} / \mathrm{g})$, and vitamin $\mathrm{A}$ $(6.23 \mu \mathrm{g} / \mathrm{g})$ and vitamin $\mathrm{C}(0.54 \mathrm{mg} / \mathrm{g})$ and this was followed by horse gram $(342.50 \mu \mathrm{g} / \mathrm{g}$; $12.05 \mathrm{mg} / \mathrm{g} ; 8.00 \mathrm{mg} / \mathrm{g} ; 1.73 \mathrm{mg} / \mathrm{g} ; 0.20 \mu \mathrm{g} / \mathrm{g}$; $4.52 \mu \mathrm{g} / \mathrm{g}$ and $0.43 \mathrm{mg} / \mathrm{g}$ ). Murcia et al., (2002) reported that all truffles (Terfezia and Piscoa spp.) and five mushrooms (Leptista nuda, Lentinus edodes, Agrocybe cylindracea, Cantharellus lutescens and Hydrum sepundum) exihibited higher per cent of oxidative inhibition based on lipid peroxidation, deoxyribose and peroxidase. Methanol extract of $P$. florida have potent hydroxyl radical scavenging and lipid peroxidation inhibition (antioxidant) activities. The antioxidant activities in Ganoderma lucidum, P. florida, $P$. sajor-caju, as scavenging activity was demonstrated by Lakshmi et al., (2005). Recently Prabhakara (2006) reported high level of antioxidative substances due to calcium carbonate activity in P.euos.

\section{References}

Ames, B.N., Shigena, M.K., and Hagen, T.M. 1993, "Oxidants, antioxidants and degenerative diseases of ageing. Proceedings of National Academy of Sciences" USA 90, 7915-7922.

Chang, S.T. 1974, "Production of straw mushroom (Volvariella volvacea) from cotton wastes". Mushroom J. 21, 384353.

Chang, S.T., and Miles, P.G. 1993, "Edible mushrooms and their cultivation" CBS Publishers and Distributors, New Delhi. Pp, 240.

Chang, S.T. 1977, "The origin and early development of straw mushroom cultivation" Economic Bot. 31, 374-376.

Dragsted, C.O., Strube, M. and Larsen, L.C. 1993, "Cancer protective factors in fruits and vegetables". Biochemical and biological background Pharmacology and Toxicology. 72, (suppl.) 116-135.

Duh, P.D., Yen, D.B. and Yen, G.C. 1992, "Extraction and identification of an antioxidative component from edible oils" Food Chemistry, 14, 45-51.

Frankel, E.N., Waterhouse, A.L. and Tiessedre, P. 1995, "Principal phenolic phytochemicals in selected California wines and their antioxidant activity in 
inhibiting oxidation of human low density lioproteins" J Agric Food Chem., 43, 890894.

Gaulejac, N., Vivas, N. and Borgeois, G. 1999, "The influence of various phenolics compounds on scavenging activity assessed by an enzymatic method". Journal of Science of Food and Agriculture, 79, 1081-1090.

Gazzani, G., Papetti, A., Massolini, G. and Daglia, M. 1998, "Antioxidative and prooxidant activity of water soluble components of some common diet vegetables and the effect of thermal treatment", Journal of Food Chemistry, 6, 4118-4122.

Gerester, H. 1997, "Potential role of carotene in the prevention of cardiovascular disease", Inter J Vit Nutr Res., 61, 277-291.

Hertog, M.G.L., Hollman, P.C.H. and Katan, M.B. 1992, "Content of potentially anticarcinogenic of 28 vegetables and 9 fruits commonly consumed in the Netherlands", J Agric Food Chem., 40, 2379-2383.

Joseph, J.A., Shukit-Hale, B. and Denisova, N.A. 1999, "Reversal of Age-Related declines in neuronal signal transduction, cognitive and motor behavioral deficits with blue berry, spinach or strawberry dietary supplementation", Journal of Neuroscience, 19, 8114-8812.

Krishnamoorthy, A.S., Thiribhuvanamala, G., Shanthi, K. and Marimuthu, T. 2005, "Outdoor cultivation of paddy straw mushroom as inter crop in maize field". Mushroom Res 1, 9-12.

Lakshmi, B., Tilak, J.C., Adhikari, S., Devasagayan, T.P.A. and Janardhanan, K.K. 2005, "Evaluation of antioxidant activity of selected Indian mushrooms" Inter J Pharm Biol., 42, 179-185.
Mori, K., Toyomasu, T., Narba, H. and Kuroda, H. 1989, "Antitumour action of fruit bodies of edible mushrooms orally administered to mice", Mushroom News Letter for Tropics, 7, 121-126.

Murcia, M.A., Martinez, M., Jimenez, A.M., Veera, A.M., Honrubia, M., Parras, P. 2002, "Antioxidant activity of edible fungi (truffles and mushrooms): losses during industrial processing". J Food Prot., 65, 1614-22.

Neild, Butris, C.A., and Ashwood, A. 1963, "Text book of Clinical Chemistry", 27, 1280-1282.

Prabhakara, S. 2006, "Studies on "Development of low cost technologies to boost oyster mushroom production suitable for export”, M.Sc. (Ag.) Thesis, Tamil Nadu Agrl. Univ., Coimbatore, India.

Prior, R.L. and Coa, G. 2000, "Antioxidant phytochemicals in fruits and vegetables: diet and health implications", Horticulture Science, 35, 588-592.

Saeed, M.S., Khan, M., and Imam-ul-haq, M. 1994, "Growing paddy straw mushroom on water hyacinth", Pakistan J Phytopathol., 6, 130-134.

Sumathi, S. 1998, "HIV infection and antioxidant vitamin status: Report on short course on recent advances in vitaminology", $15^{\text {th }}$ June to $4^{\text {th }}$ July 1998. A.N.G.R. Agricultural University, Hyderabad.

Thakur, M.P. and Yadav, V. 2006, "Modern techniques of cultivating paddy straw mushroom in a commercial scale". Compendium of lectures-Emerging Areas in Mushroom Diversity, Production and Post Harvest Developments. pp.10-20.

Thomas, K.M., Ramakrishan, T.S. and Narsimhalu, I.L. 1943, "Paddy straw Mushroom”, Madras Agric J., 31, 57-59.

\section{How to cite this article:}

Sudha, A., P. Geetha and Rajesh, M. 2019. Antioxidant Properties of Paddy Straw Mushroom (Volvariella volvacea (Bull. ex Fr.)) Sing. Int.J.Curr.Microbiol.App.Sci. 8(02): 3031-3036. doi: https://doi.org/10.20546/ijcmas.2019.802.355 